\section{BLASTOGENIC RESPONSES AND THE RELEASE OF INTERLEUKINS 1 AND 2 BY SPLEEN CELLS OBTAINED FROM RAT SKIN ALLOGRAFT RECIPIENTS ADMINISTERED WITH 15-DEOXYSPERGUALIN}

\section{KyUichi Nemoto and Fuminori Abe}

\author{
Research Laboratories, Pharmaceuticals Group, \\ Nippon Kayaku Co., Ltd., \\ 3-31-12 Shimo, Kita-ku, Tokyo 115, Japan

\section{TERUYA NakAMURA} \\ Central Research Laboratories, \\ Takara Shuzo Co., Ltd., \\ 3-4-1 Seta, Ohtsu-shi, Shiga-ken 520-21, Japan

\section{MASAAKI IshIZUKa, TOMIO TAKEUCHI and HAMAO UMEZAWA ${ }^{\dagger}$}

\begin{abstract}
Institute of Microbial Chemistry, 3-14-23 Kamiosaki, Shinagawa-ku, Tokyo 141, Japan
\end{abstract}

(Received for publication February 5, 1987)

15-Deoxyspergualin (DSG) is an analogue of spergualin isolated from Bacillus laterosporus ${ }^{1}$. In mice, DSG strongly inhibits antibody formation and delayed-type hypersensitivity to sheep red blood cells ${ }^{2}$. In rats, DSG inhibits the rejection of $\operatorname{skin}^{2)}$, heart ${ }^{3)}$ and islet cell ${ }^{4)}$ allografts. The mechanisms responsible for these immunosuppressive actions of DSG have not been elucidated. To investigate these mechanisms, we administered DSG or cyclosporin A (Cy A), a representative immunosuppressant ${ }^{5}$, to rats transplanted with a skin allograft. We then examined the blastogenic response and the release of interleukins 1 (IL 1) and 2 (IL 2) by spleen cells isolated from these rats.

The transplantation of rat skin was carried out as previously reported ${ }^{6}$. Male 9 weeks old Fisher 344 and SHR rats (Charles River Japan, Kanagawa, Japan) were used as recipients and donors, respectively. DSG was prepared at Takara Shuzo Co., Ltd. ${ }^{7}$. It was dissolved in saline, sterilized by passing through a $0.22 \mu \mathrm{m}$ filter, and stored at $-20^{\circ} \mathrm{C}$ until use. Cy A (Sandimmun) was purchased from Sankyo Co.,

$\dagger$ Deceased.
Ltd., Tokyo, Japan, and diluted with olive oil as required. As previously reported ${ }^{2}$, DSG dose-dependently prolonged mean survival time (MST) of the skin allograft at doses of 2 to 12.5 $\mathrm{mg} / \mathrm{kg}$, when given ip for the successive 10 days after the grafting. In a separate experiment, when Cy A was given po at doses of $12.5(n=6)$, $25(n=7)$ and $50 \mathrm{mg} / \mathrm{kg}(n=6)$ using the same schedule, the MSTs were $9.3 \pm 0.5,14.1 \pm 3.3$ and $16.0 \pm 4.4$ days (mean $\pm \mathrm{SD}$ ), respectively (control MST $=7.5 \pm 1.5$ days; $n=4$ ). The result is in agreement with the report of DenHAM et al. ${ }^{87}$. Therefore, DSG was administered ip into 6 rats at an immunosuppressive dose of $3 \mathrm{mg} / \mathrm{kg}$ once a day for 22 days from 1 day (day 1) after the transplantation. Cy A was given orally to 10 rats at a dose of $25 \mathrm{mg} / \mathrm{kg}$ following the same schedule. A control group of 7 rats received neither agent. The spleens were removed from 5 animals per group on day 23 and used in the following experiments.

RPMI 1640 medium supplemented with $10 \%$ fetal calf serum (FCS), sterptomycin $(100 \mu \mathrm{g} / \mathrm{ml})$ and benzylpenicillin (100 units/ml) was used to incubate spleen cells at $37^{\circ} \mathrm{C}$ in $5 \% \mathrm{CO}_{2}$ in air. From each group one aliquot of unseparated spleen cells was tested for blastogenic response as reported previously ${ }^{8)}$. Another aliquot of cells was used to prepare culture supernatants containing IL 1. These cells was suspended in the RPMI medium $\left(1 \times 10^{7}\right.$ cells $\left./ \mathrm{ml}\right)$, seeded into FCS-coated Falcon 3003 dishes $(10 \mathrm{ml} /$ dish) and incubated for 2 hours.

For each group the adherent cells were obtained and pooled. The pooled cells $\left(1 \times 10^{6}\right.$ cells $/ \mathrm{ml} /$ well) were incubated with $25 \mu \mathrm{g} / \mathrm{ml}$ of Escherichia coli 055: B5 lipopolysaccharide (LPS, Difco, Detroit, U.S.A.) for an additional 36 hours in 24-well Costar culture plates. The supernatants were separated and stored at $4^{\circ} \mathrm{C}$. To prepare culture supernatants containing IL 2, a third aliquot of unseparated cells $\left(2 \times 10^{6}\right.$ cells/ $\mathrm{ml} /$ well) was incubated with or without $10 \mu \mathrm{g} / \mathrm{ml}$ of concanavalin A (Con A, Sigma, St. Louis, U.S.A.) in the 24-well plates. After 48 hours incubation the supernatants were separated and stored at $4^{\circ} \mathrm{C}$. The IL 1 and IL 2 activities in the culture supernatants were determined according to Rosenwasser and DINARELlo ${ }^{9)}$ and GILlis et $a l .{ }^{10)}$, respectively. Data were analyzed by Student's t-test.

Tail skin grafts of 4 SHR donors were trans- 
Table 1. Effects of DSG and Cy A administrations on blastogenic responses of spleen cells stimulated with mitogens.

\begin{tabular}{lcc}
\hline \multirow{2}{*}{ Group } & \multicolumn{2}{c}{$\left[{ }^{3} \mathrm{H}\right] \mathrm{TdR}$ incorporation $(\mathrm{cpm})$} \\
\cline { 2 - 3 } & Con A & LPS \\
\hline Control & $130,833 \pm 18,458$ & $24,073 \pm 5,967$ \\
DSG & $359,714 \pm 182,209^{*}$ & $26,472 \pm 9,650$ \\
Cy A & $80,381 \pm 24,542^{* *}$ & $8,177 \pm 1,903^{* *}$ \\
\hline
\end{tabular}

Triplicate $0.2 \mathrm{ml}$ of the unseparated cell $\left(2 \times 10^{5}\right.$ cells) were incubated with $5 \mu \mathrm{g} / \mathrm{ml}$ of Con A or $100 \mu \mathrm{g} /$ of LPS in flat bottomed Costar 96-well plates for 72 hours and pulsed with $1 \mu \mathrm{Ci}$ of $\left[6-{ }^{3} \mathrm{H}\right]-$ thymidine $\left(\left[{ }^{3} \mathrm{H}\right] \mathrm{TdR}, 15.5 \mathrm{Ci} / \mathrm{mmol}\right.$, New England Nuclear, Boston, U.S.A.) for the last 8 hours of the incubation period. After the cells were harvested, measurement of $\left[{ }^{3} \mathrm{H}\right] \mathrm{TdR}$ incorporation into the cells was carried out in liquid scintillation counters. Data are shown as the mean $\pm S D$ of five seperate determinations.

$* P<0.05 . \quad * * P<0.01$.

planted to 23 Fisher 344 recipients. In the control group $(n=7)$, the grafts were rejected at $6.9 \pm 1.1$ days (mean $\pm \mathrm{SD}$ ) after grafting. In contrast, DSG $(n=6)$ and Cy A $(n=10)$ completely inhibited the rejection until day 23 when the spleens were removed.

Unseparated spleen cells prepared from each group were tested for their responses to Con A and LPS. As shown in Table 1, the Con A and LPS-stimulated blastogenic response of cells obtained from Cy A administered rats were significantly lower than the response of cells obtained from those control rats. In contrast, the administration of DSG did not impair the response of the cells to either mitogen. On the contrary, a significantly higher blastogenic response to Con A was observed in spleen cells obtained from the rats treated with DSG.

Adherent spleen cells were tested for their ability to release IL 1 after LPS stimulation. As shown in Table 2, the IL 1 activity was slightly lower in the cells from $\mathrm{Cy} \mathrm{A}$-treated rats (no difference statistically significant). In contrast however, a significantly higher IL 1 activity was observed in the cells from DSG-treated rats.

The effects of DSG or Cy A administration on the ability of the unseparated cells incubated with or without Con A to release IL 2 were examined. The results are shown in Table 3. Compared to control, the IL 2 activity released spontaneously and in response to stimulation
Table 2. The ability of adherent spleen cells from DSG and Cy A-treated rats to release IL 1.

\begin{tabular}{cc}
\hline Group & {$\left[{ }^{3} \mathrm{H}\right] \mathrm{TdR}$ incorporation } \\
$(\mathrm{cpm})$
\end{tabular}

Male $\mathrm{C} 3 \mathrm{H} / \mathrm{HeJ}$ mice purchased from Jackson Laboratory, Bar Harbor, U.S.A., were used as thymocyte donors. The thymocytes $\left(4 \times 10^{5}\right.$ cells $)$ were incubated for 72 hours in $0.15 \mathrm{ml}$ of the incubation medium with $1.25 \mu \mathrm{g} / \mathrm{ml}$ of Con A with $0.05 \mathrm{ml}$ of $1 / 32$ dilution of the LPS-stimulated supernatants or the incubation medium. The other testing conditions are the same as those described in the legend of Table 1. Data are shown as the mean \pm SD of triplicate determinations. The background level of $\left[{ }^{3} \mathrm{H}\right] \mathrm{TdR}$ incorporation to the cells stimulated with Con A (1.25 $\mu \mathrm{g} / \mathrm{ml})$ was $33,153 \pm 9,005 \mathrm{cpm}$.

* $P<0.05$.

Table 3. Effects of DSG and Cy A administrations on IL 2 release.

\begin{tabular}{llc}
\hline \multirow{2}{*}{ Group } & \multicolumn{3}{c}{$\left[{ }^{3} \mathrm{H}\right] \mathrm{TdR}$ incorporation (cpm) } \\
\cline { 2 - 3 } & \multicolumn{1}{c}{ - Con A } & + Con A \\
\hline Control & $16,880+4,122$ & $238,329+28,524$ \\
DSG & $23,820+6,477^{*}$ & $333,634+18,017^{* *}$ \\
Cy A & $10,344+2,753^{* *}$ & $144,154+25,125^{* *}$ \\
\hline
\end{tabular}

IL 2 activities in the supernatants from the unseparated spleen cells with or without Con A were quantitated in the presence of $1 \times 10^{4}$ CTLL-2 cells in a final volume of $0.2 \mathrm{ml}$. The cells were incubated for 18 hours, pulsed with $1 \mu \mathrm{Ci}$ of $\left[{ }^{3} \mathrm{H}\right] \mathrm{TdR}$, and further incubated for 6 hours. Measurement of the incorporation of $\left[{ }^{3} \mathrm{H}\right] \mathrm{TdR}$ into the cells was carried out as described in the legend of Table 1. Data correspond to $1 / 8$ dilution of the Con A-free supernatants and 1/256 dilution of the Con A-induced supernatants, respectively, and are shown as the mean $\pm \mathrm{SD}$ of five determinations.

* $P<0.05$. ** $P<0.01$.

by Con $\mathrm{A}$ were significantly lower in the cells from the rats treated with $\mathrm{Cy} \mathrm{A}$. The amount of IL 2 released however was found to be significantly higher in the cells from the rats treated with DSG.

These results demonstrated that the administration of Cy A at a dose of $25 \mathrm{mg} / \mathrm{kg}$ significantly reduced the blastogenic response and IL 2 re- 
lease from the spleen cells of rats receiving skin allografts. The finding on IL 2 release is in agreement with the report of ABBUD-FILHO et al. ${ }^{11}$. However, these functions of the cells were not impaired by the administration of DSG at a dose of $3 \mathrm{mg} / \mathrm{kg}$, with the exception of the blastogenic response to LPS. The findings of this study using an immunosuppressive dose of each agent suggest that the immunosuppressive agent DSG has a different mechanism of action from that of Cy A.

\section{Acknowledgment}

We thank Mr. K. TAKAHASHI for his critical discussion and Mrs. M. HaYashi, Ms. Y. Sugawara, Ms. E. HAYASH and Mr. K. Kotake for their technical assistance.

\section{References}

1) Iwasawa, H.; S. Kondo, D. Ikeda, T. TakeUCHI \& H. UMeZAWA: Synthesis of (-)-15deoxyspergualin and (-)-spergualin-15-phosphate. J. Antibiotics 35: 1665 1669, 1982

2) Nemoto, K.; M. Hayashi, F. Abe, T. NakaMURA, M. IshizUKa \& H. UMEZaWA: Immunosuppressive activities of 15-deoxyspergualin in animals. J. Antibiotics 40:561 562, 1987

3) Walter, P.; J. Thies, G. Harbauer, G. Dickneite, H. H. Sedlacek \& F. Vonnahme: Allogeneic heart transplantation in the rat with a new antitumoral drug - 15-deoxyspergualin. Transplant. Proc. 18: 1293 1294, 1986

4) Dickneite, G.; H. U. SCHORLEMmer, P. WALter \& H. H. Sedlacek: Graft survival in experimental transplantation could be prolonged by the action of the antitumoral drug 15-deoxyspergualin. Transplant. Proc. 18: 1295 1296, 1986

5) Borel, J. F.; C. Feurer, H. U. Gubler \& H. StAHELIN: Biological effects of cyclosporin A: A new antilymphocytic agent. Agents Actions 6: 468 475, 1976

6) Umezawa, H.; M. IshtzuKa, T. Takeuchi, F. Abe, K. Nemoto, K. Shibuya \& T. Nakamura: Suppression of tissue graft rejection by spergualin. J. Antibiotics 38: 283 284, 1985

7) Umeda, Y.; M. Moriguchi, H. Kuroda, T. Nakamura, H. InNuma, T. TAKeUChI \& $\mathrm{H}$. UMEZAWA: Synthesis and antitumor activity of spergualin analogues. I. Chemical modification of 7-guanidino-3-hydroxyacyl moiety. J. Antibiotics 38: 886 898, 1985

8) Denham, S.; J. M. Styles, R. K. Barfoot \& C. J. Dean: Reversible suppression of alloantibody production by cyclosporin $\mathrm{A}$. Int. Arch. Allergy Appl. Immunol. 62: 453 458, 1980

9) Rosenwasser, L. J. \& C. A. Dinarello: Ability of human leukocytic pyrogen to enhance phytohemagglutinin-induced murine thymocyte proliferation. Cell. Immunol. 63: 134 142, 1981

10) Gillis, S.; M. M. Ferm, W. OU \& K. A. Smith: $T$ cell growth factor: parameters of production and a quantitative microassay for activity. J. Immunol. 120: 2027 2032, 1978

11) ABbud-Filho, M.; J. W. KUPIEC-WeglinsKI, J. L. Araujo, C. D. Heidecke, N. L. Tilney \& T. B. Strom: Cyclosporine therapy of rat heart allograft recipients and release of interleukins (IL 1, IL 2, IL 3): A role for IL 3 in graft tolerance? J. Immunol. 133: 2582 2586, 1984 